\title{
Production of Illness with a Small-Particle Aerosol of Coxsackie $\mathrm{A}_{21}$ *
}

\author{
Robert B. Couch, Thomas R. Cate, Peter J. Gerone, William F. Fleet, \\ David J. Lang, William R. Griffith, and Vernon Knight $\dagger$ \\ (From the National Institute of Allergy and Infectious Diseases, Laboratory of Clinical \\ Investigations, Bethesda, Md., and U. S. Army Biological Laboratories,
}

Ft. Detrick, $M d$.)

In previous studies of the response of normal volunteers to inoculation with respiratory viruses, the inoculum was administered by instillation of liquid into the nose and by a hand nebulizer that delivered a coarse spray to the nasopharynx (1). Observation indicated that much of the virus given by these methods deposited in the nasopharynx, but portions were swallowed, or discharged by coughing, sneezing, or expectoration. Although these studies often resulted in viral infection and illness, it was not possible to assess accurately dose-effect relationships. Furthermore, it was apparent that a full investigation of human response to respiratory viruses should include observations on the effect of inoculation of portions of the respiratory tract other than the nasopharynx.

Inoculation with aerosol offered the possibility of attaining the above objectives. The site of deposition of particles within the respiratory tract and the number of particles deposited is a function of the particle size $(2,3)$. It is thus possible to estimate with some accuracy both the site of viral deposition and the amount of virus deposited when aerosols of known particle size containing known amounts of virus are inhaled. Therefore, when preliminary studies demonstrated the feasibility of the use in human volunteers of a small-particle aerosol containing Coxsackie $\mathrm{A}_{21}$ virus (4), and the properties of the aeorsol had been determined (5), observations were made on the response of volunteers to graduated doses of the aerosol utilizing three different inocula of Coxsackie $A_{21}$.

\footnotetext{
* Submitted for publication October 6, 1964 ; accepted December 3, 1964.

$\dagger$ Address requests for reprints to: Dr. Vernon Knight, National Institute of Allergy and Infectious Diseases, Bethesda, Md. 20014.
}

\begin{abstract}
Methods
Volunteers. Volunteers were healthy adult males from several Federal correctional institutions, and the arrangements by which they participated have been described in detail elsewhere (6). They were housed three to a room and placed in isolation for 2 to 4 days before and 10 to 14 days after inoculation. Examinations were performed daily by physicians having no knowledge of which of several respiratory agents was administered to a particular volunteer.
\end{abstract}

Virus. The strains of Coxsackie $A_{21}$ used in these studies were recovered from Marines at Camp Lejeune, N. C., who were infected during the 1959 outbreak (7, 8). Strain 49882 was passaged once in human embryonic kidney tissue culture (HEK) and had a concentration of $10^{6.3} \mathrm{TCID}_{\text {so }}$ per $\mathrm{ml}$. The details of preparation, identification, and safety testing of this inoculum have been previously reported (1). A second pool prepared from strain 48654 was passaged twice in Wistar-26 human embryonic lung fibroblast tissue cultures (HEF) (9) and concentrated 100 -fold in the following manner: after one freeze-thaw cycle, the harvest of passage 2 was centrifuged at $2,000 \mathrm{rpm}$ for 20 minutes and the supernate passed through an $800-\mathrm{m} \mu$ Millipore filter. The filtrate was concentrated 10 -fold by vacuum dialysis, ${ }^{1}$ and the concentrate was then homogenized with equal volumes of Genetron in a Virtis " 45 " homogenizer for 6 separate 1-minute intervals. The aqueous and organic layers were separated by centrifugation at $2,000 \mathrm{rpm}$ for 2 minutes, and the aqueous layer received an additional 10 -fold concentration by addition of $0.5 \%$ gelatin and centrifugation at $105,000 \mathrm{~g}$ for 3 hours in a Spinco model L preparative centrifuge. The resuspended pellets were pooled and distributed in glass ampules, which were sealed and stored at $-70^{\circ} \mathrm{C}$. This inoculum had a viral concentration of $10^{9.2} \mathrm{TCID}_{\mathrm{so}}$ per $\mathrm{ml}$ and was safety tested in a previously described manner (10). A third inoculum pool was prepared from three throat swab specimens that were also obtained from Marine Corps recruits at Camp Lejeune, N. C. These specimens were pooled without tissue culture passage, diluted, safety-tested, and stored at $-70^{\circ} \mathrm{C}$ until used.

Inoculation. Volunteers received aerosol inoculation by

1 Ultrafilter LKB 6300A from LKB-Produkter AB, Stockholm 12, Sweden, was used for this procedure. 
means of a molded rubber face mask attached to a cylindrical chamber containing a continuous flow of aerosol approximately 10 seconds old at the time of inoculation. This equipment and other necessary auxiliary components were contained in a mobile truck semitrailer and have been previously described $(4,11)$. Each man inhaled 10 $\mathrm{L}( \pm 5 \%)$ through the nose and exhaled by mouth into a discharge bag. Each inoculation required 30 to 60 seconds and followed a training period on a previous day with the same equipment.

Aerosol properties. The size of particles in the aerosol ranged from 0.2 to $3.0 \mu$ in diameter. Particles 1 to $2 \mu$ in diameter comprised $54 \%$ of the total particle volume and contained $68 \%$ of recoverable virus. The standard deviation among aerosol viral concentrations during periods of administration was $0.25 \log _{10}$ TCID 50 . The log concentration of virus in the aerosol expressed as a function of the $\log$ concentration of virus in the suspension used to generate the aerosol was a straight line with a slope of 0.87 . This finding made it possible to predetermine with a reasonable degree of accuracy the dose to be administered to volunteers.

Viral isolation and identification procedures. Nose and throat swabs were obtained from each volunteer before inoculation, daily for 7 days after inoculation, and 3 times weekly for an additional 14 to 18 days. Each swab was agitated in $2 \mathrm{ml}$ of veal infusion broth containing $0.5 \%$ bovine albumin and antibiotics, and the specimen fluid was stored at $-20^{\circ} \mathrm{C}$. Specimens were tested for the presence of virus by inoculating $0.4 \mathrm{ml}$ of specimen fluid into one HEK or HEF tissue culture tube that contained $1.5 \mathrm{ml}$ of equal parts medium 199 and Eagle's MEM, 2\% inactivated calf serum, and antibiotics. The cultures were incubated in a roller drum turning at $12 \mathrm{rph}$ at 33 to $34^{\circ} \mathrm{C}$, and observed for cytopathic effect for 14 days. Tissue culture fluid and cells were harvested when enterovirus cytopathic effect involved 75 to $100 \%$ of the cell sheet. The first and last isolates from nasal and throat swab specimens were identified by hemagglutination-inhibition ( $\mathrm{HI}$ ) with 20 antibody units of specific hyperimmune guinea pig serum $(7,12)$.
Serologic tests. Tests for neutralizing antibody were performed in HEK or HEF tissue cultures in a manner previously described. (7). All neutralizing antibody titers, calculated by the method of Karber, are expressed as the initial dilution of serum completely inhibiting cytopathic effect of 32 to $100 \mathrm{TCID}_{50}$ of Coxsackie $\mathrm{A}_{21}$ (13). HI antibody titers are expressed as the initial serum dilution inhibiting hemagglutination by 4 hemagglutinin units of Coxsackie $A_{21}$.

\section{Results}

Determination of $50 \%$ human infectious dose. Forty-two volunteers free of detectable antibody were inoculated with a range of doses of small particle Coxsackie $A_{21}$ aerosol. Twenty-eight of these received strain $49882 \mathrm{HEK}_{1}$, and 14 received strain $48654 \mathrm{HEF}_{2}$. The doses, the number of volunteers inoculated, and the number infected, as determined by viral isolation and antibody rise, are shown in the first 3 columns of Tables I and II. Based on these findings the $50 \%$ human infectious dose $\left(\mathrm{HID}_{50}\right)$ for strain 49882 corresponds to $28 \mathrm{TCID}_{50}$ (Spearman-Karber method) with $95 \%$ confidence limits of 15 to 49 , and for strain 48654 the $\mathrm{HID}_{50}$ corresponds to $34 \mathrm{TCID}_{50}$ with $95 \%$ confidence limits of 22 to 52 (14). Only 2 of the 26 infected volunteers (676 and 71 $\mathrm{TCID}_{50}$, Table I) failed to develop illness, indicating that the human $50 \%$ infectious dose and $50 \%$ illness dose are nearly the same.

Patterns of illness. The predominant pattern of illness seen in each volunteer is also shown in Tables I and II. The incubation period in these cases was usually 3 to 4 days, and illness usually lasted 2 to 3 days. Fever rarely exceeded $38.5^{\circ} \mathrm{C}$

TABLE I

Clinical response of antibody-free $(<1: 2)$ volunteers inoculated with $0.3-$ to $2.5-\mu$ particle aerosol of Coxsackie $A_{21}\left(49882 H E K_{1}\right)^{*}$

\begin{tabular}{|c|c|c|c|c|c|c|c|}
\hline \multirow[b]{3}{*}{$\begin{array}{c}\text { Inhaled } \\
\text { dose } \\
\text { (TCID }\end{array}$} & \multirow[b]{3}{*}{$\begin{array}{c}\text { No. } \\
\text { volun- } \\
\text { teers }\end{array}$} & \multirow[b]{3}{*}{$\begin{array}{l}\text { No. } \\
\text { infected }\end{array}$} & \multirow[b]{3}{*}{$\begin{array}{c}\text { No. } \\
\text { ill }\end{array}$} & \multicolumn{4}{|c|}{ No. with indicated illness } \\
\hline & & & & \multicolumn{3}{|c|}{ Febrile $\left(\geq 37.5^{\circ} \mathrm{C}\right)$} & \multirow[b]{2}{*}{$\begin{array}{c}\text { Afebrile } \\
\text { URI }\end{array}$} \\
\hline & & & & $\begin{array}{l}\begin{array}{l}\text { Pneu- } \\
\text { monia }\end{array} \\
\end{array}$ & $\begin{array}{c}\text { Tracheo- } \\
\text { bronchitis }\end{array}$ & URI & \\
\hline $\begin{array}{r}832 \\
676 \\
316 \\
83 \\
71 \\
47 \\
18 \\
6\end{array}$ & $\begin{array}{l}1 \\
3 \\
3 \\
2 \\
5 \\
4 \\
4 \\
6\end{array}$ & $\begin{array}{l}1 \\
3 \\
3 \\
2 \\
5 \\
3 \\
1 \\
0\end{array}$ & $\begin{array}{l}1 \\
2 \\
3 \\
2 \\
4 \\
3 \\
2 \\
2\end{array}$ & 1 & $\begin{array}{l}1 \\
1 \\
2 \\
1 \\
4 \\
1\end{array}$ & $\begin{array}{l}1 \\
1 \\
1\end{array}$ & $\begin{array}{l}1 \dagger \\
2 \dagger\end{array}$ \\
\hline
\end{tabular}

* $49882 \mathrm{HEK}_{1}=$ strain passaged once in human embryonic kidney tissue culture; URI = upper respiratory illness. $\dagger$ No infection. Human infectious dose $50\left(\mathrm{HID}_{50}\right)=28$ TCID $_{50}(95 \%$ confidence limits of 15 to 49$)$. 
TABLE II

Clinical response of antibody-free $(<1: 2)$ volunteers inoculated with 0.3- to 2.5- $\mu$ particle aerosol of Coxsackie $A_{21}$ $\left(48654 \mathrm{HEF}_{2}\right)^{*}$

\begin{tabular}{|c|c|c|c|c|c|c|}
\hline \multirow{3}{*}{$\begin{array}{l}\text { Inhaled } \\
\text { dose } \\
\left(\mathrm{TCID}_{\mathbf{5 0}}\right)\end{array}$} & \multirow{3}{*}{$\begin{array}{l}\text { No. } \\
\text { volun- } \\
\text { teers }\end{array}$} & \multirow[b]{3}{*}{$\begin{array}{c}\text { No. } \\
\text { infected }\end{array}$} & \multirow[b]{3}{*}{ No. } & \multicolumn{3}{|c|}{ No. with indicated illness } \\
\hline & & & & \multicolumn{2}{|c|}{ Febrile $\left(\geq 37.5^{\circ} \mathrm{C}\right)$} & \multirow[b]{2}{*}{$\begin{array}{c}\text { Afebrile } \\
\text { URI }\end{array}$} \\
\hline & & & & $\begin{array}{c}\text { Tracheo- } \\
\text { bronchitis }\end{array}$ & URI & \\
\hline 676 & 3 & 3 & 3 & & 2 & 1 \\
\hline 54 & 2 & 2 & 2 & & 2 & \\
\hline 49 & 3 & 2 & 2 & & 2 & \\
\hline 28 & 3 & 1 & 2 & & 1 & $1+$ \\
\hline 16 & 3 & $\mathbf{0}$ & 1 & & & $1 \dagger$ \\
\hline
\end{tabular}

* $48654 \mathrm{HEF}_{2}=$ strain passaged twice in Wistar-26 human embryonic lung fibroblast tissue cultures.

$\dagger$ No infection. Human infectious doseso $\left(\right.$ HID $\left._{50}\right)=34$ TCID $50(95 \%$ confidence limits of 22 to 52 ).

and usually persisted for less than 1 day. As shown in Table I, 12 of the 18 infected volunteers who received strain $49882 \mathrm{HEK}_{1}$ (including the 2 cases later shown to have pneumonia) were clinically diagnosed as febrile acute tracheobronchitis. Characteristic of this syndrome was the occurrence of tracheal and chest pain, the latter usually substernal, and deep cough occurring in paroxysms and associated with chest discomfort. Cough was usually nonproductive although auscultation of the chest occasionally revealed scattered rhonchi. The lower respiratory tract symptoms were accompanied by symptoms of systemic illness including malaise, myalgias, chilly sensations, sweats, headache, and anorexia. Illness was not limited to the lower respiratory tract, however, since 9 of these 12 volunteers with tracheobronchitis illness also had evidence of upper respiratory tract illness that was characterized by rhinorrhea and nasal obstruction. In addition, 2 of the 12 volunteers had roentgenographic evidence of bronchopneumonia. The details of the course of one of the volunteers who developed bronchopneumonia are shown in Figure 1. The predominant illness in 4 of the 18 volunteers infected with strain 49882 was upper respiratory although one of these also had cough. The remaining 2 volunteers infected with this strain had evidence of infection without any apparent illness.

In contrast to the predominant lower respiratory tract illness seen with strain $49882 \mathrm{HEK}_{1}$, the predominant response was upper respiratory illness with strain $48654 \mathrm{HEF}_{2}$. As shown in Table II, none of the 8 volunteers infected with

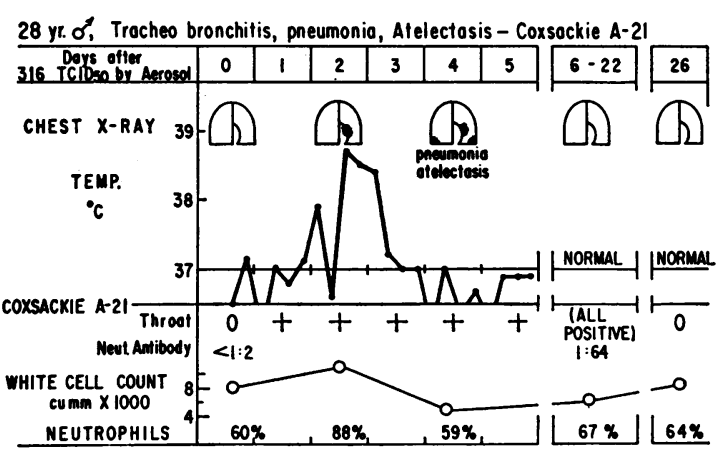

Fig. 1. CASE RePort SUMmary OF A VOLUNTEER WHO iNHALED 316 TCID $_{50}$ of CoXsaCKIE A $A_{21}$, STRAIN 49882, HUMAN EMBRYONIC KIDNEY TISSUE CULTURE (HEK ${ }_{1}$ ), BY SMALL-PARTICLE AEROSOL.

strain $48654 \mathrm{HEF}_{2}$ developed a predominant picture of tracheobronchitis. However, in all other aspects, height and duration of fever, incubation period, and systemic symptoms, the illness responses to both strains were similar.

The incubation period, severity of illness, and anatomical site of involvement for all reported illnesses did not exhibit any definite relationship to inoculating dose. Illness was brief in volunteers receiving both inocula. In 21 of the 22 febrile volunteers, fever was of less than 24 hours duration. Although the total duration of clinically detectable illness varied between 2 to 13 days, most cases were ill for only 2 to 3 days. Often a volunteer would be well one morning, have fever, systemic symptoms, and tracheobronchitis that evening, and exhibit only mild afebrile upper respiratory illness (URI) during the remaining days of illness.

A mild rhinitis not associated with viral infection was seen in five volunteers who received low doses of virus (Tables I and II). In order to elucidate the cause of this illness, groups of volunteers were given either a placebo inoculation of air, or virus that was previously inactivated with specific hyperimmune guinea pig serum prepared against virus propagated in $\mathrm{KB}$ tissue cultures. Three volunteers received air, five received 676 $\mathrm{TCID}_{50}$ of inactivated strain 49882 , and three received a similar dose of inactivated strain 48654 . Other volunteers were simultaneously inoculated with the same material not previously inactivated and are included in Tables I and II. No illness occurred in the men given air, but one man in each group who received inactivated virus developed a 


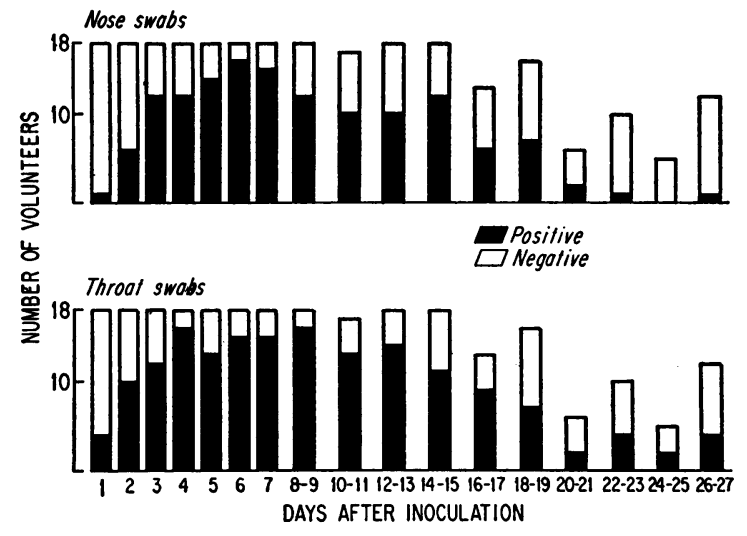

Fig. 2. TEMPORAL SHEDDING OF VIRUS FROM NOSE AND THROAT OF VOLUNTEERS WHO INHALED SMALL-PARTICLE AERosols of CoXSACKIE $A_{21}$, Strain 49882 HEK $_{1}$

mild afebrile URI that was not associated with evidence of infection.

Viral shedding. The patterns of shedding from the nose and throat for strain $49882 \mathrm{HEK}_{1}$ are shown in Figure 2 . Viral shedding began between days 1 and 4 after inoculation and tended to be earlier in the high dosage groups. Maximal recovery rates from the nose and throat occurred during the first 15 days after inoculation. Thereafter, shedding became erratic and recovery rates progressively decreased. A similar shedding pattern occurred for strain $48654 \mathrm{HEF}_{2}$. Since virus was recovered from 20 of the 26 infected volunteers on one or both of the last 2 days cultures were obtained, the total duration of shedding by these men cannot be assessed. During the first

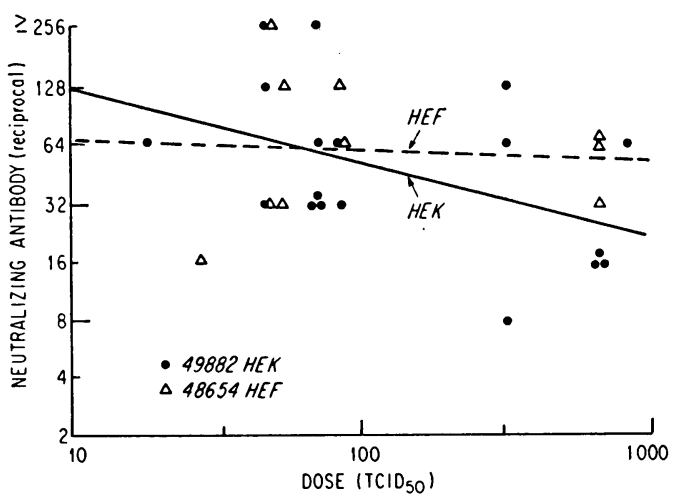

Fig. 3. Relation of inhaled dose to titer of NeUTRALIZING ANTIBODY ATTAINED BY 3 TO 4 WEEKS AFTER INOCULATION AMONG VOLUNTEERS INOCULATED WITH SMALL-PARTICle AERosols of CoXSACKIE $A_{21}$. Slope of line best fitting each group is shown.
15 days after inoculation, 55 to $60 \%$ of nose and throat swabs from subjects given strain 49882 $\mathrm{HEK}_{1}$ and throat swab cultures from those given strain $48654 \mathrm{HEF}_{2}$ contained virus. During the same period $70 \%$ of nose swabs from the latter group of volunteers were positive.

Antibody responses. The neutralizing antibody responses 3 to 4 weeks postinoculation are shown in Figure 3. All volunteers who shed virus developed a greater than 4-fold antibody response, and none of the volunteers who failed to shed virus developed antibody. The magnitude of the neutralizing antibody response exhibited by volunteers who received strain $49882 \mathrm{HEK}_{1}$ decreased with increasing dose of virus administered $(\mathrm{r}=-0.451, \mathrm{p}<0.05$, Spearman's rank correlation test) (14). This relationship was not seen after inoculation with strain $48654 \mathrm{HEF}_{2}(\mathrm{r}=$ $0.0, p>0.10)$. The relationship between neutralizing and $\mathrm{HI}$ antibody responses are shown in Figure 4. All volunteers who developed neutralizing antibody also developed $\mathrm{HI}$ antibody, and the magnitude of each response was similar $(r=$ $0.418, \mathrm{p}<0.05$, Spearman's rank correlation test).

Nasal secretions. Nasal secretions were quantitated as previously described for 8 days postinoculation on 20 of the volunteers who received strain $49882 \mathrm{HEK}_{1}$ (10 infected, 10 uninfected) (1). Measurable rhinorrhea occurred in 4 of 10 infected volunteers, and the frequency of occurrence of rhinorrhea in these volunteers decreased as inoculum dose decreased ( $p<0.05$, permutation test) (14). There was no increase in rhinorrhea in uninfected men.

Neutrophil counts. A rise and fall in the number of peripheral blood neutrophils occurred during the first 3 days after inoculation. Although this change occurred in both infected and noninfected volunteers, the magnitude was significantly greater in the infected volunteers. In addition, a late rise in neutrophil counts occurred 14 to 20 days after inoculation in the infected volunteers. A drop in lymphocyte counts occurred among infected subjects at the time of illness, but a drop of similar magnitude occurred at a later period in uninfected volunteers.

Effect of pre-existing serum antibody. Eight volunteers with varying levels of preinoculation antibody were given 500 to $1,000 \mathrm{TCID}_{50}$ of 


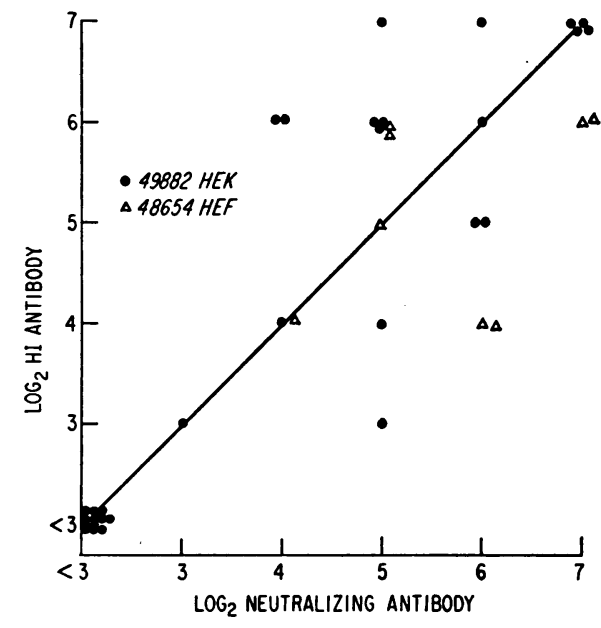

Fig. 4. Relation of magnitude of NeUtralizing ANTIBODY ATTAINED BY 3 TO 4 WEEKS AFTER INOCULATION TO MAGNITUDE OF HEMAGGLUTINATION-INHIBITING ANTIBODY AMONG VOLUNTEERS INOCULATED WITH SMALL-PARticle aerosols of CoXsackie $A_{21}$.

strain $49882 \mathrm{HEK}_{1}$ by aerosol (Table III). Three were infected as determined by viral isolation and antibody rise. The illness seen in these individuals was milder and the period of viral shedding was shorter (mean 5 days) than that seen in infected antibody-free volunteers. The three men with the highest titers $(>256)$ had acquired this antibody after nasopharyngeal inoculation with Coxsackie $\mathrm{A}_{21}$ about 4 months earlier. All three of these individuals developed an afebrile nasal illness with no detectable infection. No consistent pattern of leukocyte changes or nasal secretion results occurred in these eight volunteers.

Inoculation with natural virus. In order to evaluate the effect of tissue culture passage on infectivity and virulence, an inoculum containing

TABLE III

Response of volunteers with preinoculation antibody to inoculation with a small-particle aerosol of Coxsackie $A_{21}$

\begin{tabular}{cccccc}
\hline \hline $\begin{array}{c}\text { Reciprocal } \\
\text { preinoc- } \\
\text { ulation } \\
\text { antibody }\end{array}$ & $\begin{array}{c}\text { Inhaled } \\
\text { dose } \\
\text { (TCID }\end{array}$ & $\begin{array}{c}\text { No. } \\
\text { volun- } \\
\text { teers }\end{array}$ & $\begin{array}{c}\text { No. } \\
\text { with } \\
\text { isiala- } \\
\text { ison }\end{array}$ & $\begin{array}{c}\text { No. } \\
\text { with } \\
\text { tiond } \\
\text { anti- } \\
\text { body } \\
\text { rise }\end{array}$ & $\begin{array}{c}\text { No. } \\
\text { ill }\end{array}$ \\
\hline 256 & 500 & 3 & 0 & 0 & $3^{*}$ \\
64 & $500-1,000$ & 2 & 1 & 1 & 0 \\
$16-32$ & $500-1,000$ & 3 & 2 & 2 & $2 \dagger$ \\
\hline
\end{tabular}

* All three illnesses were mild rhinitis. † One afebrile URI and one febrile URI. throat swab specimens from three persons with natural Coxsackie $\mathrm{A}_{21}$ illness was administered by aerosol. No evidence of infection or illness occurred in six volunteers who received 7 TCID $_{50}$ of infectious virus or in three volunteers who received this inoculum inactivated with specific hyperimmune guinea pig serum. Two volunteers were inoculated with $28 \mathrm{TCID}_{50}$ of this pool by reducing the air dilution of the aerosol and administering a $20-\mathrm{L}$ inoculation. One of the volunteers became infected. He developed a febrile upper respiratory illness and exhibited a pattern of viral shedding and antibody response similar to that seen in volunteers who received the tissueculture-grown virus.

\section{Discussion}

In these studies estimates have been made of the $\mathrm{HID}_{50}$ of 2 strains of Coxsackie $\mathrm{A}_{21}$ that had been passaged in tissue cultures of human origin and administered in a small-particle aerosol. Each strain had an $\mathrm{HID}_{50}$ of approximately $30 \mathrm{TCID}_{50}$ of virus; however, since these estimates were based on inhaled doses, of which only 50 to $75 \%$ was retained $(2,3)$, the actual $\mathrm{HID}_{50}$ were considerably less than $30 \mathrm{TCID}_{50}$. Virus obtained from naturally occurring cases of illness but not passaged in tissue culture was also given, and the results suggest that this inoculum had about the same degree of infectivity.

Despite the nearly identical $\mathrm{HID}_{50}$ and the other similarities, the anatomic distribution of the illness responses was quite different. Strain 49882 frequently caused tracheobronchitis, which in two cases was accompanied by roentgenographic evidence of pneumonia, whereas no lower respiratory tract illness occurred in those volunteers inoculated with strain 48654 . Both strains caused about the same degree of upper respiratory tract involvement.

In a previous study antibody-free volunteers were inoculated in the nasopharynx by coarse spray and drops with $3,000 \mathrm{TCID}_{50}$ of strain 49882 HEK $_{1}$ (1). These men developed upper respiratory illness only, which is in contrast to the finding that this same inoculum given by smallparticle aerosol produced both upper and lower respiratory illness. Thus the disparity in distribution of illness resulting when two different 
strains (49882 $\mathrm{HEK}_{1}$ and $48654 \mathrm{HEF}_{2}$ ) were separately administered by the same method was also seen when two different methods were used to administer strain $49882 \mathrm{HEK}_{1}$. The question arises as to the possible causes for these findings.

The following evidence indicates that there is a marked difference in sites of deposition of virus administered by coarse spray and drops and by small-particle aerosol. In the former method, virus was administered by instillation with a pipette and with a no. 127 DeVilbiss hand atomizer. Excess material given by pipette was swallowed or expectorated. The type of atomizer used has been shown to produce a coarse spray (15), which by calculation can be shown to be trapped almost exclusively in the nasopharynx $(2,3)$. Hence, inoculation of volunteers by this procedure results almost entirely in deposition of virus in the nasal passages and posterior pharynx.

In contrast to this deposition pattern, 80 to $90 \%$ of particles in the size range ( 0.2 to $3.0-\mu$ diameter) present in the small-particle aerosol will bypass the nasopharynx and be carried to peripheral areas of the lung. The remaining 10 to $20 \%$ will be trapped in the nasopharynx $(2,3)$. Since the volunteers inhaled a $10-\mathrm{L}$ dose of aerosol in approximately 10 breaths, a volume larger than the usual tidal volume, it seems likely that complete exchange of alveolar air occurred. Such a result would provide opportunity for virus in the 80 to $90 \%$ of particles that bypassed the nasopharynx to deposit in the alveoli. About one-half of particles reaching the alveoli and adjacent areas will deposit, primarily due to gravity settling. Thus, virus contained in this small-particle aerosol will be deposited throughout the respiratory tract from the nose to the alveoli, but with the greatest concentration in the peripheral areas of the lungs.

These statements are based on the assumption that the particles in the aerosol, which is prepared at 50 to $60 \%$ humidity, did not increase greatly in size as a result of absorption of water in the moisture-saturated air of the respiratory passages. Studies in chambers with controlled humidity indicate that similar aerosol particles increase in size by as much as 2.0 to 2.5 times when exposed to $90 \%$ relative humidity (5). If the virus were contained in particles $3 \mu$ in diameter, about $40 \%$ would be removed in the nasal passages and tracheobronchial tree, and deposition in the pulmonary lobules would fall appreciably $(2,3)$. However, regardless of any change in size that may occur, substantial deposition in lower respiratory sites is assured.

It is thus apparent that if viral infection were established at the sites of deposition, this would account for the development of upper respiratory illness in those volunteers inoculated by coarse spray and drops (49882 $\mathrm{HEK}_{1}$ ) and lower respiratory tract illness in those volunteers inoculated with the same strain by means of smallparticle aerosol. The deposition of aerosol inoculum in the nasopharynx would account for the upper respiratory illness as well as the recovery of virus from the nasopharynx before and simultaneously with the onset of illness in all groups. However, since presumably both inocula given by aerosol would have had similar patterns of deposition, the absence of lower respiratory tract disease in volunteers given strain $48654 \mathrm{HEF}_{2}$ by aerosol cannot be explained by considering site of deposition of virus as the prime factor in determining anatomic localization of disease. Therefore, other factors must act to offset the anticipated tendency for lower respiratory deposition to lead to lower respiratory disease.

The contrasting illness responses to the two inocula given by aerosol can probably be explained by differing properties of the viral particles making up each inoculum. Strain 49882 was recovered from an individual with a febrile upper respiratory illness, whereas strain 48654 was recovered from one with an afebrile upper respiratory illness. Thus far, no laboratory evidence of a difference in properties has been found; however, nasal cultures from volunteers given strain $48654 \mathrm{HEF}_{2}$ were more often positive than those from strain $49882 \mathrm{HEK}_{1}$. In view of the marked differences in histology and physiology of the upper and lower respiratory tracts (16-18) a converse relationship might occur with respect to growth of these strains in the lower respiratory tract.

An alternative mechanism by which differences in the viral strains might cause differences in localization of infection and illness is the process of removal of foreign material from the lung. Studies with inert particulates have shown that pulmonary macrophages probably constitute the most 
important mechanism for removal of foreign material from the pulmonary lobule. Although some of this removal takes place through the lymphatic system, most is conveyed by macrophages to the mucociliary apparatus that transports it upward through the tracheobronchial tree to the pharynx. It may be that strain $48654 \mathrm{HEF}_{2}$ was more efficiently removed so that infectivity was reduced below threshold values. This same mechanism may account for the tracheal disease in those volunteers who received strain $49882 \mathrm{HEK}_{1}$ even though evidence indicates that little virus deposited in this site. Survival of influenza virus in macrophages has been demonstrated, and it has been suggested that macrophages act as a mechanism of spread for this agent (19).

The contrasting responses to these two Coxsackie $A_{21}$ inocula may involve mechanisms more complex than those that have been discussed. Despite similarities in methods of inoculation and in strains of virus that might lead one to expect similar illness responses, significant differences in patterns of disease occurred, which indicates the need for further study of this problem.

The relevance of the present studies to those responses that occur during naturally occurring infection cannot be precisely assessed at the present time. However, sneezing and coughing produce significant numbers of particles of a size that remain airborne for long periods of time (20). Since throat and nose secretions from persons with naturally and experimentally induced infections with Coxsackie $A_{21}$ contain $10^{4-6} \mathrm{TCID}_{50}$ per $\mathrm{ml}$, it is reasonable to suppose that the smallparticle aerosol produced by sneezing or coughing may contain the small quantity of virus required to infect man $(21,22)$. Thus the method of smallparticle aerosol inoculation used in this study may closely resemble the mechanism of initiation of naturally occurring infection.

\section{Summary}

Estimates were made of the $50 \%$ human infectious dose $\left(\mathrm{HID}_{50}\right)$ of two strains of Coxsackie $\mathrm{A}_{21}$ that had been passaged in tissue cultures of human origin and administered in a small-particle $(0.2$ to $3.0 \mu)$ aerosol. Each strain had an $\mathrm{HID}_{50}$ of approximately $30 \mathrm{TCID}_{50}$ of virus. Virus obtained from naturally occurring cases of illness but not passaged in tissue culture was also given, and the results suggested a similar degree of infectivity.

The syndrome of illness produced by a strain passed in human embryonic kidney tissue culture was principally a febrile tracheobronchitis, and 2 of 16 cases of illness developed roentgenographic evidence of pneumonia. In contrast, illness with a different strain passed in human embryonic lung fibroblast tissue culture was characteristically a febrile upper respiratory illness. Illness was associated with a moderate neutrophilia that was followed by a second elevation in neutrophil counts at about 10 days postinoculation. Virus was recovered frequently from the nose and throat in infected subjects, and evidence of infection usually persisted throughout the 3-week period of observation. Significant elevation of neutralization and hemagglutination-inhibiting antibody occurred in all infected subjects. The magnitude of antibody response produced by one of the inocula was inversely related to the dose of virus administered. Subjects with detectable serum antibody before inoculation exhibited milder illness and less viral shedding.

\section{Acknowledgments}

We thank Mr. Holly A. Smith, Mrs. Carol Uhlendorf, Mr. James Turner, Mr. Leonard P. Durocher, and Mr. Donald L. Hollabaugh for their technical work; Mr. Edward B. Derrenbacher and Mr. Charles O. Masemore, U. S. Army Biological Laboratories, Ft. Detrick, Md., for assisting with the aerosol inoculation; and the following who materially assisted in the program: $\mathrm{Mr}$. James Bennett, Director, and Dr. Charles E. Smith, Chief Medical Officer, Bureau of Prisons, U. S. Department of Justice; Dr. Clifton K. Himmelsbach, Associate Director, and Mr. Franklyn Gray, Assistant Supervisor, Normal Volunteer Program, Clinical Center, National Institutes of Health. Dr. David Alling kindly performed the statistical analyses. The volunteers are commended for their excellent cooperation.

\section{References}

1. Spickard, A., H. Evans, V. Knight, and K. Johnson. Acute respiratory disease in normal volunteers associated with Coxsackie A-21 viral infection. III. Response to nasopharyngeal and enteric inoculation. J. clin. Invest. 1963, 42, 840.

2. Hatch, T. R., and P. Gross. Pulmonary Deposition and Retention of Inhaled Aerosols. New York, Academic Press, 1964. 
3. Davies, C. N. Deposition of dust in the lungs; a physical process in Industrial Pulmonary Diseases, E. J. King and C. M. Fletcher, Eds. Boston, Little, Brown, 1960, pp. 44-58.

4. Knight, V., P. J. Gerone, W. R. Griffith, R. B. Couch, T. R. Cate, K. Johnson, D. J. Lang, H. E. Evans, A. Spickard, and J. A. Kasel. Studies in volunteers with respiratory viral agents. Amer. Rev. resp. Dis. 1963, 88, 135.

5. Couch, R. B., P. J. Gerone, T. R. Cate, W. R. Griffith, D. W. Alling, and V. Knight. Preparation and properties of a small-particle aerosol of Coxsackie A-21. Proc. Soc. exp. Biol. (N. Y.), in press.

6. Knight, V. The use of volunteers in medical virology in Progress in Medical Virology, E. Barger and J. L. Melnick, Eds. Basel, S. Karger, 1964, pp. 2-26.

7. Johnson, K. M., H. H. Bloom, M. A. Mufson, and R. M. Chanock. Acute respiratory disease associated with Coxsackie A-21 virus infection. I. Incidence in military personnel: observations in a recruit population. J. Amer. med. Ass. 1962, 179, 112.

8. Bloom, H. H., K. M. Johnson, M. A. Mufson, and R. M. Chanock. Acute respiratory disease associated with Coxsackie A-21 infection. II. Incidence in military personnel: observations in a nonrecruit population. J. Amer. med. Ass. 1962, 179, 120.

9. Hayflick, L., and P. S. Moorhead. The serial cultivation of human diploid cell strains. Exp. Cell Res. 1962, 25, 585.

10. Couch, R. B., R. M. Chanock, T. R. Cate, D. J. Lang, V. Knight, and R. J. Huebner. Immunization with types 4 and 7 adenovirus by selective infection of the intestinal tract. Amer. Rev. resp. Dis. 1963, 88, 394.
11. Griffith, W. R. A mobile laboratory unit for exposure of animals and human volunteers to bacterial and viral aerosols. Amer. Rev. resp. Dis. 1964, 89, 240.

12. Rosen, L. A hemagglutination-inhibition technique for typing adenoviruses. Amer. J. Hyg. 1960, 71, 120.

13. Finney, D. J. Statistical Method in Biological Assay, London, Charles Griffin, 1952, pp. 524-530.

14. Siegel, S. Nonparametric Statistics for the Behavioral Sciences. New York, McGraw Hill, 1956, p. 202.

15. Rosebury, T. Experimental Air-Borne Infection. Baltimore, Williams \& Wilkins, 1947, p. 78.

16. Maximow, A. A., and W. Bloom. A Textbook of Histology. Philadelphia, W. B. Saunders, 1957, pp. 430-449.

17. Bang, F. B. Mucociliary function as protective mechanism in upper respiratory tract. Bact. Rev. 1961, 25, 228.

18. West, J. B., C. T. Dollery, and P. Hugh-Jones. Pulmonary gas exchange measurements using radioactive gases in Ciba Foundation Symposium on Pulmonary Structure and Function. Boston, Little, Brown, 1962, pp. 159-170.

19. Davenport, F. M. Pathogenesis of influenza. Bact. Rev. 1961, 25, 294.

20. Duguid, J. P. The size and the duration of air-carriage of respiratory droplets and droplet-nuclei. J. Hyg. (Lond.) 1946, 44, 471.

21. Mufson, M. A., K. M. Johnson, H. H. Bloom, and R. M. Chanock. Multiplication and cytopathology of Coxsackie A-21 virus in rotated and stationary tissue culture. Proc. Soc. exp. Biol. (N. Y.) 1962, 110, 198.

22. Couch, R. B., P. J. Gerone, V. Knight, and associates. Unpublished observations. 